УДК 342.565.2:341.231.14(09)

DOI https:// doi.org/10.32837/yuv.v0i5.2004

\title{
Н. Шелевер,
}

кандидатка юридичних наук, доцентка, доцентка кафедри адміністративного, фінансового та інформаційного права ДВНЗ «Ужгородський національний університет»

\section{КОНСТИТУЦІЙНЕ ПРАВО НА СПРАВЕДЛИВИЙ СУД У КОНТЕКСТІ СТАТТІ 6 КОНВЕНЦІЇ ПРО ЗАХИСТ ПРАВ ЛЮДИНИ І ОСНОВОПОЛОЖНИХ СВОБОД 1950 РОКУ}

У зв'язку із прагненням України стати повноправним членом Європейського Союзу важливим питанням сьогодення є забезпечення та реалізація права на справедливий суд, що $€$ ключовим елементом європейських стандартів правосуддя. 17 липня 1997 р. Україна ратифікувала Конвенцію про захист прав людини та основоположних свобод (далі Конвенція) та протоколи до неї, які стали складовою частиною національного законодавства, та взяла на себе зобов'язання гарантувати і реалізувати передбачене Конвенцією право на справедливий суд.

Це питання досліджували такі вчені, як: В. Буткевич, О. Лемак, П. Рабінович, М. Савчин, С. Шевчук та інші. Мета статті полягає в аналізі сучасного розуміння права на справедливий суд у практиці Європейського суду з прав людини (далі - ЄСПЛ) та його структурних елементів.

У зв'язку із приєднанням нашої держави до Конвенції кожна особа має право звернутися до ЄСПЛ як до найвищої інстанції для встановлення справедливості у вирішенні свого спору. У ст. 6 Конвенції визначено право на справедливий суд як право особи на справедливий i публічний розгляд справи упродовж розумного строку незалежним і безстороннім судом, встановленим законом, який вирішить спір щодо цивільних прав та обов'язків особи або встановить обгрунтованість будь-якого висунутого проти особи кримінального обвинувачення.

$\mathrm{y}$ рішеннях ЄСПЛ принцип справедливості судового розгляду тлумачать як право на доступ до правосуддя, належне здійснення правосуддя, рівність сторін тощо. Проблемою $€$ те, що жоден документ не містить визначення поняття «справедливий судовий розгляд». Тому важливим питанням $є$ встановлення сутності поняття «справедливий судовий розгляд» та аналіз рішень ЄСПЛ, які його визначають.

Право на справедливий суд складається з таких елементів, як: право доступу до судової процедури; право на справедливий розгляд упродовж розумного строку незалежним і безстороннім судом, встановленим законом; право на публічний розгляд справи; право брати участь у судовому розгляді справи, маючи рівні можливості з іншою стороною тощо.

В узагальненні практики застосування Київським окружним адміністративним судом Конвенції про захист прав людини та основоположних свобод 1950 р., практики Європейського суду з прав людини під час розгляду та вирішення адміністративних справ зазначається: «Основні конвенційні вимоги стосовно доступу до суду ЄСПЛ виклав у рішеннях, ухвалених проти України («Плахтєєв та Плахтєєва проти України», 
«Меньшакова проти України», «Чуйкіна проти України») та проти інших держав - учасниць Конвенції («Голдер проти Сполученого Королівства», «Кутіч проти Хорватії, «Ашингдейн проти Сполученого Королівства», «Креуз проти Польщі»).

У п. 1 ст. 6 кожному право гарантоване на звернення до суду з позовом щодо його прав та обов'язків цивільного характеру. Таким чином, він втілює у собі «право на суд», яке, згідно із практикою ЄСПЛ, включає в себе не тільки ініціювати провадження, але й право розраховувати на «розгляд» спору судом. Право на суд не $є$ абсолютним і може підлягати легітимним обмеженням, таким, наприклад, як передбачені законом строки давності, заходи забезпечення позову, нормативне регулювання такого права стосовно неповнолітніх та психічно хворих осіб (рішення у справі «Стаббінгс та інші проти Сполученого Королівства» ("Stubbings and Others v. the United Kingdom”) від 22 жовтня 1996 р, «Толстой-Милославський проти Сполученого Королівства" ("Tolstoy-Miloslavsky v. the United Kingdom") від 13 липня 1995 р.). Якщо доступ до суду обмежено внаслідок дії закону або фактично, Суд має з'ясувати, чи не порушило встановлене обмеження саму суть цього права, зокрема, чи мало воно законну мету, і чи існувало відповідне пропорційне співвідношення між застосованими засобами і поставленою метою (рішення у справі «Ашингдейн проти Сполученого Королівства" ("Ashingdane v. the United Kingdom") від 28 травня 1985 p.) [1].

В. Комаров та Н. Сакара зазначають: «Уявляється, що право на справедливий судовий розгляд слід аналізувати в широкому й вузькому значенні. У широкому значенні це право закріплене в п. 1 ст. 6 Конвенції й ототожнюється із правом на доступ до правосуддя, тобто кожна особа повинна мати можливість ініціювати судовий розгляд справи щодо своїх цивільних прав і свобод та отримати справедливий i ефективний судовий захист. Також особа повинна мати безпосередній доступ, не обтяжений якимись юридичними чи фактичними перешкодами, до судової установи, а розгляд справи мусить відбуватися 3 додержанням усіх вимог, що передбачені п. 1 ст. 6 Конвенції про захист прав людини та основних свобод, оскільки мова не може йти про справедливий судовий розгляд, якщо справа вирішена, наприклад, з порушенням вимоги публічності, розумності строків, незалежності чи безсторонності суддів тощо.

У вузькому значенні право на справедливий судовий розгляд охоплює лише вимогу «справедливої» процедури, яка в тексті статті Конвенції про захист прав людини та основоположних свобод використовується поряд із вимогами незалежності та безсторонності суду, публічності й розумності строку судового розгляду. Даючи дефініції справедливості у вузькому значенні, Європейський суд 3 прав людини виділяє й такі вимоги, які не вказані в п. 1 ст. 6 Конвенції, наприклад, належне сповіщення та слухання, взяття до уваги судом лише доказів, отриманих законним шляхом, винесення обгрунтованого рішення, принцип рівності сторін у змагальному процесі, заборону втручання законодавця у процес здійснення правосуддя, принцип правової певності. 3 метою уникнення тавтологій право на справедливий судовий розгляд у вузькому значенні має називатися правом на належну судову процедуру» $[2$, с. $15-16]$.

В узагальненні практики застосування Київським окружним адміністративним судом Конвенції про захист прав людини та основоположних свобод 1950 р., практики Європейського суду з прав людини під час розгляду та вирішення адміністративних справ зазначається: «Прикладом застосування Київським окружним 
адміністративним судом гарантій щодо розгляду справи незалежним та неупередженим судом $є$ справа № 810/2525/18 ОСОБА_1 до Територіального управління Державної судової адміністрації в Київській області та Державної судової адміністрації України про визнання неправомірними дій та зобов'язання вчинити певні діi. У рамках цієї справи головуючим суддею у справі було заявлено заяву про самовідвід, вирішуючи яку по суті, суд зазначив, що ст. $6 \mathrm{KoH}-$ венції про захист прав людини і основоположних свобод встановлює право на справедливий судовий розгляд. Кожна людина при визначенні іiі громадянських прав та обов'язків або при висуненні проти неї будь-якого обвинувачення, має право на справедливий і відкритий розгляд упродовж розумного строку незалежним і безстороннім судом.

Щодо безсторонності Європейський суд з прав людини висуває дві вимоги: по-перше, бути об'єктивно безстороннім - тобто суд повинен гарантувати виключення будь-якого обгрунтованого сумніву стосовно його безсторонності. Щоб задовольнити ці вимоги, суд повинен відповідати суб'єктивному й об'єктивному тесту: безсторонність для цілей п. 1 ст. 6 Конвенції повинна визначатися суб'єктивним тестом, тобто на підставі особистого переконання окремого судді в даній справі і за об'єктивним тестом. Тобто з'ясування, чи має суддя гарантії, достатні для виключення будь-якого законного сумніву стосовно його безсторонності» [1].

Важливими елементами права на справедливий суд $є$ принцип публічності та право на розумний строк розгляду справи. Відповідно до ст. 6 Конвенції, кожна людина має право на те, щоб іï справа розглядалася публічно. Не може бути таємне правосуддя, бо інакше не буде довіри до суду.

На думку Е. Трегубова, «ЕСПЛ поширює вимогу щодо розумності строків не тільки на розгляд справи в суді, але і на виконання судового рішення. У справі «Бурдов проти Росії ЄСПЛ прямо вказує, що право на звернення до суду, закріплене у ст. 6 Конвенції, було б ілюзорним, якби правова система країн - учасниць Конвенції допускала, що судове рішення, яке набрало законної сили та $є$ обов'язковим для виконання, залишилося би не чинним щодо однієї зі сторін усупереч іiі інтересам. Тлумачення ст. 6 Конвенції у світлі принципу верховенства права вимагає більш широкого підходу, за яким формальності не можуть бути підставами для виправдання несправедливості. Отже, не можна уявити, що ст. 6 Kонвенції, захищаючи право на розумний строк розгляду справи, не передбачала би захисту права на виконання судового рішення» [3, с. 361].

3 метою реалізаціі принципу справедливості суди повинні під час здійснення правосуддя застосовувати Конвенцію про захист прав людини та основоположних свобод і практику Європейського суду з прав людини.

У висновках Великої палати Верховного Суду, які сформульовані нею під час розгляду справи № $9901 / 386 / 18, \quad$ провадження № 11-85заі18, зазначається: «Завданням адміністративного судочинства відповідно до ч. 1 ст. 2 КАС є справедливе, неупереджене та своєчасне вирішення судом спорів у сфері публічно-правових відносин із метою ефективного захисту прав, свобод та інтересів фізичних осіб, прав та інтересів юридичних осіб від порушень із боку суб'єктів владних повноважень.

Справедливість судового рішення передбачає, що такі рішення мають достатньою мірою висвітлювали мотиви, на яких вони грунтуються. Межі такого обов'язку можуть різнитися залежно від природи рішення і мають оцінюватись у світлі обставин кожної справи. Національні суди, коли вибирають аргументи та приймають докази, мають обов'язок

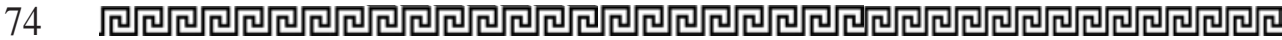


обгрунтувати свою діяльність шляхом наведення підстав для такого рішення. Отже, суди мають дослідити основні доводи (аргументи) сторін та 3 особливою прискіпливістю й ретельністю - змагальні документи, що стосуються прав та свобод, гарантованих Конвенцією про захист прав людини і основоположних свобод 1950 р.» [4].

Уважаємо такий висновок Великої палати Верховного Суду дуже доречним. Усі обставини справи мають бути ретельно досліджені, перевірені всі доводи обох сторін. Лише в такому разі досягається справедливість судового розгляду.

Усі аргументи, які сторони вважають важливими, мають бути розглянуті судом. Рішення є справедливим лише за тієї умови, якщо всі обставини справи перевірені та підтверджені відповідними доказами. У цьому полягає й обгрунтованість судового рішення.

Ю. Матат уважає: «Не менш важливою складовою частиною права на справедливий суд, гарантованого ст. 6 Конвенції, є своєчасне виконання остаточного судового рішення. Так, Європейський суд з прав людини в рішенні у справі "Hornsby $v$. Greece" зазначив, що право на справедливий суд було б ілюзорним, якби національна правова система договірної держави допускала невиконання остаточного й обов'язкового судового рішення на шкоду одній зі сторін. Обов'язковість виконання судових рішень, разом з іншими складовими частинами права на справедливий суд, зокрема такими, як доступ до суду, суб'єктивна неупередженість суду, принцип правової визначеності, заборона втручання законодавця у відправлення правосуддя, розглядаються Судом як елементи верховенства права ("Golder v. The United Kingdom”, app. no. 4451/70)» [5, c. 33].

ЄСПЛ неодноразово висловлював свою стурбованість стосовно недосконалості національного механізму юридичного захисту в Україні, що пов'язане з невиконанням чи неналежним виконанням судових рішень. Проблемним питанням під час виконання рішень ЄСПЛ є те, що державний виконавець, як представник органу державної влади, отримує заробітну плату з державного бюджету України, але зобов'язаний, згідно з виконавчими документами, діяти проти власної держави.

Ю. Тобота зазначає: «Таким чином, різні підходи до розуміння категоріï «справедливість» дають підставу визначити іiі в узагальненому вигляді як: 1) чесність, порядність, неупередженість (об'єктивність) у відносинах між суб'єктами права, відповідність таких відносин моральним та правовим нормам; 2) певне співвідношення (пропорційність) між злочином та покаранням, працею та винагородою; 3) рівність правового статусу суб'єктів права. Водночас в останньому випадку про рівність може йтися в сенсі здійснення правосуддя національними судами та Судом, у яких учасники провадження мають рівні процесуальні права й обов'язки. Отже, термін «справедливий» у процесуальному аспекті означає неупереджений (незалежний) та об'єктивний, такий, що рівною мірою (без привілеїв) враховує інтереси учасників судового провадження, відповідає моральним та правовим нормам» [6, с. 66].

Важливим критерієм справедливого судового розгляду є неупередженість судді. Так, суддя має однаково ставитися до сторін, не може бути жодних привілеїв чи обмежень.

Ю. Тобот зауважує: «Тому зміст поняття «справедливого судового розгляду» у справах, що їх розглядає Суд, охоплює зокрема вимоги щодо рівного доступу до правосуддя, публічності розгляду справ, гарантування права обвинуваченому у вчиненні кримінального правопорушення бути детально повідомленим про характер і мотиви висунутого проти нього обвинувачення, необхідності надання йому достатнього 
часу та можливостей для підготовки свого захисту, можливості захищати себе особисто або обрати для цього захисника, у тому числі безкоштовно, допитувати свідків обвинувачення й захисту. Окрім зазначених критеріїв справедливого судового розгляду, до них належать також усі ті права, які закріплено у відповідних процесуальних кодексах (кримінальному, цивільному, адміністративному тощо) та дотримання яких під час здійснення відповідного виду судочинства буде відповідати інтересам підозрюваного, обвинуваченого, потерпілого, заявника, позивача тощо (наприклад, право заявляти клопотання, давати пояснення та інші)» [6, с. 68].

С. Степанова зазначає: «<...> Удосконалення механізму застосування Конвенції про захист прав людини і основоположних свобод та практики Європейського Суду в національному законодавстві та національній судовій практиці потребує застосування таких практичних механізмів, як: внесення змін до чинного законодавства та практики його застосування, забезпечення юридичної експертизи законопроєктів, перевірка на відповідність чинних законів, належне опублікування, швидке й ефективне розповсюдження на національному рівні тексту рішень Суду серед суддів, прокурорів, адвокатів, працівників правоохоронних органів та інших категорій працівників, професійна діяльність яких пов'язана із правозастосуванням, а також тримання людей в умовах позбавлення волі, забезпечення їх професійної підготовки 3 питань вивчення Конвенції та практики Європейського суду тощо» [7, с. 4-5].

Уважаємо, щоб побудувати європейську Україну, потрібно гарантувати та реалізувати на практиці конституційне право людини на справедливий суд. Пріоритетним під час здійснення правосуддя має бути саме принцип справедливості. Конституція України закріплює основні засади судочинства. Проте засада справедливості не закріплена там. На нашу думку, було б доцільно додати до Конституції Україн принцип справедливості.

С. Степанова вважає: «Право на справедливий суд $€$ основоположним правом людини, важливим елементом права в демократичній та правовій державі. Наявність ефективної судової системи є гарантією забезпечення «формального» та «реального» верховенства права. Водночас принципи верховенства права, правової визначеності та належного здійснення правосуддя становлять основу права на справедливий суд. Функціонування права на справедливий суд $€$ підІрунтям для системи права загалом, гарантією захисту всіх інших прав. Оскільки принципи пріоритету загальнолюдських цінностей, справедливості, рівності та свободи є аксіологічними імперативами, то право на справедливий суд у цьому контексті передбачає втілення всіх морально-ціннісних надбань людства» [7, с. 29].

Забезпечення справедливого судочинства залежить насамперед від моральних якостей судді. На жаль, в Україні спостерігається ситуація, коли існують так звані «тіньові суди». Громадяни України, які знають рівень корумпованості українських суддів, шукають будь-яких можливих способів впливу на них із метою позитивного вирішення справи. Тому суддями мають ставати особи з високою правовою свідомістю, культурою і бажанням реалізувати на практиці справедливе правосуддя, а не імітацію судового процесу.

Справедливість - цее одна з фундаментальних иінностей, яка захищзає основні права і свободи людини i громадянина. Завданням судової гілки влади є утвердження принципу справедливості. Європейська конвенція про захист прав людини $і$ основоположних свобод закріплюе права i свободи людини. Вона ратифікована Україною та є складовою частиною національного законодавства. 
Конвениія гарантуе право на справедливий суд. Конвенція та протоколи до неї стали складовою частиною національного законодавства. Україна взяла на себе зобов'язання гарантувати $і$ реалізувати передбачене Конвениією право на справедливий суд, яке є основоположним правом людини. Практика Європейського суду з прав людини має пріоритет над нормами національного законодавства. Проте для вдосконалення механізму застосування Конвениіі треба забезпечити юридичну експертизу законопроєктів.

Україна має прагнення стати повноцінним иленом Європейського Союзу, тому повинна забезпечити і право на справедливий суд. Це ключовий елемент європейських стандартів правосуддя. Право на справедливий суд є комплексом конституційно закріплених процесуальних прав. Кожна людина прагне, щоб їі справа розглядалася в суді справедливо.

Жоден документ не містить визначення поняття «справедливий судовий розгляд». Тому важливим питанням є встановлення сутності поняття «справедливий судовий розгляд» $i$ аналіз рішень Европейського суду з прав людини, які його визначають.

Ключовими елементами права на справедливий суд є: право доступу до судової процедури; право на справедливий розгляд упродовж розумного строку незалежним $i$ безстороннім судом, встановленим законом; право на публічний розгляд справи; право брати участь у судовому розгляді справи, маючи рівні можливості з іншою стороною тощо. Конвенція гарантуе кожному право на звернення до суду з позовом щодо його прав $i$ обов'язків ичивільного характеру.

У рішеннях Європейського суду з прав людини принцип справедливості судового розгляду тлумачать як право на доступ до правосуддя, належне здійснення правосуддя, рівність сторін. На практиці дуже часто спостерігається ситуація, коли суди лише формально посилаються на принцип справедливості. Правосуддя є справедливим лище тоді, коли всі обставини справи ретельно досліджені, перевірені всі доводи обох сторін. Проблемним питанням в Україні є виконання судових рішень, оскільки навіть справедливі судові рішення на практиці часто-густо взагалі не виконуються. Під час здійснення правосуддя суддя має керуватися принципом справедливості, бути неупередженим, оскільки ие є важливим критерієм справедливого судового розгляду.

Ключові слова: справедливість, право на справедливий суд, Європейський суд з прав людини, правосуддя, Конвенція про захист прав людини та основоположних свобод.

Shelever N. The constitutional right to a fair trial under article 6 of the Convention for the protection of human rights and fundamental freedoms $\mathbf{1 9 5 0}$

Justice is one of the fundamental values that protects the fundamental rights and freedoms of man and citizen. The task of the judiciary is the adoption of the principle of fairness. The European Convention for the protection of human rights and fundamental freedoms enshrines the rights and freedoms of the individual. It is ratified by Ukraine and is part of the national legislation. The Convention guarantees the right to a fair trial. The Convention and its Protocols have become an integral part of national legislation. Ukraine has committed itself to guarantee and realize the envisaged Convention right to a fair trial, which is a fundamental human right. Practice of the European court of human rights takes precedence over national law. However, to improve the mechanism 
of application of the Convention it is necessary to provide a legal expertise of draft laws.

Ukraine has a desire to become a full member of the European Union, it must therefore ensure the right to a fair trial. This is a key element of European standards of justice. Right to a fair trial is a complex of constitutional procedural rights. Each person seeks to have her case heard in court fairly.

Neither document does contain the definition of "fair trial". Therefore, an important issue is to establish the nature of "fair trial" and analysis of ECHR judgments that define it.

Key elements of the right to a fair trial is the right to access the judicial process; right to a fair hearing within a reasonable time by an independent and impartial Tribunal established by law; right to public hearing; the right to participate in judicial proceedings, having equal opportunities with the other party, and the like. The Convention guarantees the right to appeal to court with a claim concerning his rights and obligations of a civil nature.

The decisions of the ECHR the principle of a fair trial is interpreted as the right to access to justice, the proper administration of justice, the equality of the parties. In practice, very often there is a situation when the courts only formally invoke the principle of justice. Justice is fair only when all the circumstances of the case are thoroughly researched, all the arguments on both sides are tested. A problematic issue in Ukraine is the enforcement of judicial decisions, because even a fair judicial decisions in practice are often not implemented. When administering justice, judges should be guided by the principle of justice, to be impartial, because it is an important criterion of a fair trial.

Key words: justice, right to fair trial, European Court of Human Rights, justice, European Convention for protection of human rights.

\section{Література}

1. Узагальнення практики застосування Київським окружним адміністративним судом Конвенції про захист прав людини та основоположних свобод 1950 р., практики Європейського суду з прав людини під час розгляду та вирішення адміністративних справ. URL: https: / / adm.ko.court.gov.ua / sud1070/ pokazniki-diyalnosti/uzagalinenja_1/ Uzagaljnenja_zastosuvanja_Konvencii_ praktuku_ESPL_2018 (дата звернення: 17.08.2020)

2. Комаров В., Сакара Н. Право на справедливий судовий розгляд у изивільному судочинстві. Харків : Наи. юрид. акад. імені Ярослава Мудрого, 2007. 42 с.

3. Трегубов Е. Право на справедливий суд у практиці Європейського суду з прав людини. Форум права. 2010. № 1. С. 358-363.

4. Висновки Великої палати Верховного Суду (справа № 9901/386/18). URL: http: / / www.reyestr.court.gov.ua/ Reviеw/74022208 (дата звернення: 17.08.2020)

5. Матат Ю. Право на справедливий суд: практика Європейського суду з прав людини і реалізація в Україні. Науковий вісник Ужгородського національного універсuтemy. 2016. Bun. 41 (1). C. 31-36.

6. Тобота Ю. Поняття та критеріі «справедливого судового розгляду» у рішеннях Європейського суду з прав людини. Вісник Харківського національного університету імені В.Н. Каразіна. 2013. № 1086. C. 65-68.

7. Степанова C.B. Європейські стандарти права на справедливий суд та їх імплементація у національне законодавство Украйни: конституційно-правове дослідження: дис. ... канд. юрид. наук: 12.00.02. Київ ; Ужгород, 2018. 216 с. 